Journal of Environmental Engineering and Science

Volume 10 Issue JS4

Soybean peroxidase-catalysed removal of benzidines from water

Altahir, Feng, Jasim et al.
Journal of Environmental Engineering and Science, 2015, 10(4), 73-80 http://dx.doi.org/10.1680/jenes.15.00018 Paper 15.00018

Received 14/10/2015; accepted 22/01/2016

Published online 22/02/2016

Keywords: environmental engineering/industrial wastes/waste management \& disposal

ICE Publishing: All rights reserved

\title{
Soybean peroxidase-catalysed removal of benzidines from water
}

\section{Bahaa Malik Altahir}

Department of Chemistry, University of Al-Mustansiryah, Baghdad, Iraq; Department of Civil and Environmental Engineering, University of Windsor, Windsor, ON, Canada

\section{Wei Feng}

Department of Chemistry and Biochemistry, University of Windsor,

Windsor, ON, Canada

Hadi Hassan Jasim BSc, MSc, PhD

Assistant Professor, Department of Chemistry, University of Al-Mustansiryah, Baghdad, Iraq

\section{Keith E. Taylor}

Department of Chemistry and Biochemistry, University of Windsor,

Windsor, ON, Canada (corresponding author: taylor@uwindsor.ca)

\section{Niharendu Biswas}

Department of Civil and Environmental Engineering, University of Windsor, Windsor, ON, Canada

Jatinder K. Bewtra

Department of Civil and Environmental Engineering, University of Windsor, Windsor, ON, Canada

Sabah A. A. Jassim

Department of Civil and Environmental Engineering, University of Windsor, Windsor, ON, Canada; Applied Bio Research Inc., Windsor, ON, Canada

Crude soybean peroxidase (SBP), isolated from soybean seed coats (hulls) at unusually low concentrations, catalyses the oxidative polymerisation of hazardous aqueous benzidine and its 3,3'-dichloro, 3,3'-dimethyl and 3,3'-dimethoxy derivatives in the presence of hydrogen peroxide. The optimum operating conditions for oxidation of $0.10 \mathrm{mM}$ benzidine were investigated. At $\mathrm{pH}$, the hydrogen peroxide-to-substrate concentration ratio was 1.5 and the minimum SBP concentration required to achieve at least $95 \%$ conversion of the benzidine in synthetic wastewater was $0.43 \mathrm{mU} / \mathrm{ml}$. Progress curves were established for the conversion of the four substrates, and apparent first-order rate constants were derived. Enzyme-catalysed polymerisation with SBP and subsequent removal of the polymeric products generated can provide an alternative means to conventional methods for treating many aromatic wastewater pollutants, including the benzidines studied here.

\section{Introduction}

Benzidine (BZ) is a moderately persistent pollutant in the environment, and the exposure of populations to disposed BZ waste is a matter of great concern with regard to human health (Karim et al., 2012). BZ derivatives, as xenobiotic organic pollutants, could be generated from tannery wastewater containing large amounts of dyes and pigments after photolysis, heating or biological treatment (Saeed, 2014). These compounds are highly toxic, carcinogenic, mutagenic, teratogenic, stable in water, almost non-biodegradable and irremovable with conventional water treatment technology; thus, they are internationally recognised as priority pollutants (Azim, 2000; Lakshmi et al., 2003). BZ-based azo dyes are widely used in dye manufacturing, textile dyeing, coloured paper printing and leather industries (Powell et al., 1979). In 1980s, the US National Institute for Occupational Safety and Health published a survey of data on the carcinogenicity of BZ-based dyes from tests with experimental animals and epidemiological studies of workers exposed to the dyes, due to dye biotransformation to BZ (Chung and Stevens, 1993; Karim et al., 2012). Many of these dyes find their way into the environment by way of wastewater facilities (Zougar et al., 2014). They also exhibit a high resistance to microbial degradation in wastewater treatment systems (Bayramoglu and Yakup, 2007).
It has been shown that commercially used dyes based on BZ and its derivatives can be metabolised in the human body, releasing free aminobiphenyls (Cerniglia et al., 1982). At the same time, $\mathrm{BZ}$ is a strong carcinogen that causes cancer in the bladder, the liver and mammary glands and also results in the development of carcinoma in the thyroid glands in animals (Sentchouk and Grintsevich, 2004). Aromatic amines, such as BZ, initiate bladder cancer in humans (Lakshmi et al., 2003). Without adequate treatment, these dyes can remain in the environment for a long period of time (Hao et al., 2000). BZ and other aromatic amines, such as $o$-tolidine and $o$-dianisidine, were found to be liver, mammary gland and intestine carcinogens (Beland and Kadlubar, 1985). BZ has been found in at least 27 of the 1430 National Priorities List sites identified by the US Environmental Protection Agency (Muneer et al., 2002).

Recent studies of BZ and its derivatives, including azo dyes, involved many chemical, physical and biological treatments, including various chemical oxidation methods such as oxidation by reactive nitrogen oxygen species (Lakshmi et al., 2003), chlorine dioxide oxidation (Cao et al., 2007), dark Fenton reaction and solar driven photo-Fenton process (Hao et al., 2000); various physicochemical methods such as photochemical degradation in 
different halomethane solvents (Azim, 2000), photo-catalysed degradation (Muneer et al., 2002) and oxidation on cationic clay surfaces in aqueous suspension (Do Nascimento et al., 2006); and various biological approaches using organisms such as bacteria, fungi and helminths (Chung and Stevens, 1993) as well as native and heat-treated white rot fungus (Bayramoglu and Yakup, 2007). These methods suffer from various drawbacks such as high cost, incomplete removal, formation of hazardous by-products, low efficiency, high energy requirements and/or applicability only in a low concentration range (Nicell et al., 1993).

The long-term goal of this study is to determine whether, and if so, under what circumstances, enzymatic treatment with a peroxidase may overcome these drawbacks in a cost-effective manner (Steevensz et al., 2009). Peroxidases catalyse the oxidisation of phenols (Al-Kassim et al., 1994; Caza et al., 1999; Wilberg et al., 2002; Yu et al., 1994) and anilines (Saha et al., 2008) to form aromatic radicals in the presence of hydrogen peroxide $\left(\mathrm{H}_{2} \mathrm{O}_{2}\right)$. These radicals diffuse from the active site of the enzyme into the solution, where they couple non-enzymatically to form dimers. If the dimers are soluble and still phenolic or anilino, they become substrates for another enzymatic cycle, forming higher oligomers. The cycle continues until the polymer generated reaches its solubility limit and precipitates out of solution, later to be removed by filtration or sedimentation (Al-Ansari et al., 2009; Dunford, 1999).

Oxidation by hydrogen peroxide catalysed by thyroid peroxidase (TP) has been found to be effective in the removal of BZ from wastewater with $95 \%$ or higher efficiency (Sentchouk and Grintsevich, 2004). The main drawback in using TP is its unavailability in large quantity at a price appropriate for waste treatment (Sentchouk and Grintsevich, 2004). However, bitter gourd peroxidase (BGP) has been investigated for its ability to oxidise BZ, but a high concentration of this enzyme was needed to oxidise more than $90 \%$ of BZ (Karim et al., 2012). An immobilised laccase has also been investigated because of its ability to oxidise BZs, analogous to the oxidative ability of peroxidases (Karagoz et al., 2011).

Soybean peroxidase (SBP), an oxidoreductase extracted from the soybean seed coat (Sessa and Anderson, 1981; Dunford, 1999), has several features that recommend it for wastewater treatment. Above all, SBP can be certainly cheaper than TP, since it is easily extracted from soybean seed coats, which are a waste product of the soybean processing industry (Wilberg et al., 2002). A crude SBP extract has been found to be more efficient than the purified one (Flock et al., 1999), as are the peroxidases cited earlier, and it is active over a broad range of pH (3-5-8.0) (Caza et al., 1999; Kamal and Behere, 2003; Wright and Nicell, 1999). SBP has a higher thermal stability (being active at $70^{\circ} \mathrm{C}$ ) than other peroxidases (McEldoon and Dordick, 1996), and it is less susceptible to irreversible inactivation by peroxide. In keeping with the long-term goal given at the outset, the hypothesis to be tested here is that SBP is an efficient catalyst for treatment of the target compounds. Preliminary optimisation of
SBP-catalysed polymerisation of aqueous BZ and its 3,3'-dichloro (DCB), 3,3'-dimethyl (DMB) and 3,3'-dimethoxy (DMXB) derivatives has been carried out.

\section{Materials and methods}

Materials

Crude dry solid SBP (Enzyme Commission (EC) number 1.11.7, industrial grade lot number $18541 \mathrm{NX}$, Reinheitszahl value of $0.75 \pm$ $0 \cdot 10$ ) was obtained from Organic Technologies (Coshocton, $\mathrm{OH}$, USA). Dry solid bovine liver catalase (EC 1.11.1.6, lot number 120H7060, $19900 \mathrm{U} / \mathrm{mg}$ solid) was purchased from Sigma Chemical Company Inc. (St. Louis, MO, USA). The BZs (all with a purity of $\geq 98.0 \%$ ) were obtained from Aldrich Chemical Corporation (Milwaukee, WI, USA). All other chemicals were of analytical grade and purchased from either Sigma Chemical Company Inc., Aldrich Chemical Corporation or $\mathrm{BDH}$ Inc. (Toronto, ON, Canada).

\section{Analytical equipment}

BZ concentrations were analysed with a high-performance liquid chromatography system with ultraviolet detection (HPLC-UV) obtained from Waters Corporation (Milford, MA, USA). The system consisted of a binary HPLC pump, an auto sampler, a dual absorbance detector and a C18 reverse-phase column $(5 \mu \mathrm{m}, 4.6 \mathrm{~mm}$ $\times 150 \mathrm{~mm}$ ) operated by Breeze software. Elutions were isocratic (detection at $280 \mathrm{~nm}$ ) with a mobile phase consisting of methanol and water with a ratio of 50:50 and a flow rate of $1 \mathrm{ml} / \mathrm{min}$ for $\mathrm{BZ}$ alone and a ratio of $60: 40$ and a flow rate of $0.8 \mathrm{ml} / \mathrm{min}$ for the mixture (BZ, DCB, DMB and DMXB). The injection volume was $10 \mu 1$.

A Hewlett Packard diode array spectrometer (model 8453), with a wavelength range between 190 and $820 \mathrm{~nm}$ and a $2 \mathrm{~nm}$ resolution and controlled by a Hewlett Packard Vectra ES/12 computer, was used to measure sample absorbance. Quartz semi-microspectrometer cells with a $1 \mathrm{~cm}$ optical path length were supplied by Hellma Canada Limited (Concord, ON, Canada).

The laboratory filtration system, which was an all-glass filter holder assembly with a glass funnel, a fritted base, a cap, a clamp, a $47 \mathrm{~mm}$ membrane filter, a vacuum connector and a receiving flask connected by ground glass outer and inner joints, was supplied by Merck Millipore.

\section{Analytical methods}

\section{Colorimetric assay for SBP activity}

Enzyme catalytic activity in units (U) is defined as the number of micromoles of hydrogen peroxide converted per minute at $\mathrm{pH} 7 \cdot 4$ and $23^{\circ} \mathrm{C}$ in a standard, 'Trinder-type' assay described previously (Wu et al., 1997). One unit by this assay corresponds to $8 \mathrm{U}$ by the standard guaiacol activity assay (Sessa and Anderson, 1981). A colorimetric assay was used for measuring free SBP activities. The reaction mixture contained $40 \mathrm{mmol} / \mathrm{l}$ phosphate buffer $(\mathrm{pH}=7 \cdot 4)$, $10 \mathrm{mmol} / \mathrm{l}$ phenol and $0 \cdot 2 \mathrm{mmol} / \mathrm{l}$ hydrogen peroxide and $2 \cdot 4 \mathrm{mmol} / \mathrm{l}$, 
Soybean peroxidase-catalysed removal of

benzidines from water

Altahir, Feng, Jasim et al. 4-aminoantipyrine (AAP) in a total volume of $950 \mu 1$. The reaction was then started by adding $50 \mu 1$ of diluted enzyme sample, and the initial rate of colour formation at $510 \mathrm{~nm}$ was monitored for $30 \mathrm{~s}$. The sample dilution was adjusted according to the expected enzyme activity (to have about $0 \cdot 2$ absorbance change in $30 \mathrm{~s}$ ) (Feng et al., 2013; Steevensz et al., 2009).

\section{Colorimetric assay for hydrogen peroxide}

This assay determined the concentration of hydrogen peroxide present in the solution by measuring the colour intensity resulting from oxidative coupling of phenol and AAP in the presence of hydrogen peroxide at $\mathrm{pH} 7 \cdot 4$ with Arthromyces ramosus peroxidase as the enzymatic catalyst. The product of such reaction is a pink quinoneimine chromophore, identical to that in the preceding enzyme assay, with an absorption maximum at $510 \mathrm{~nm}$ (Steevensz et al., 2009).

\section{Buffer preparation}

The buffers used were prepared according to Gomori (1955). An acetic acid-sodium acetate buffer was used in the $\mathrm{pH}$ range $3 \cdot 0-5 \cdot 8$, and a monobasic-dibasic sodium phosphate buffer was used in the $\mathrm{pH}$ range 5.6-8.0; a $\mathrm{pH}$ higher than 9.0 was achieved with a sodium bicarbonate-sodium carbonate buffer.

\section{Experimental protocol}

Batch reactors consisted of $20 \mathrm{ml}$ of a buffered mixture of a BZ, hydrogen peroxide and SBP. Generally, the reactors were stirred using magnetic stirrers and Teflon-coated stir bars at a room temperature of about $21^{\circ} \mathrm{C}$. The components of the sample mixture were added in the following order: water (distilled or tap water),
$40 \mathrm{mM}$ acetate, phosphate or carbonate buffer, a BZ as aqueous stock solution, SBP to appropriate concentration and hydrogen peroxide to appropriate concentration to initiate the reaction. The batch reactors were stirred gently for $3 \mathrm{~h}$ open to the atmosphere, after which the samples were quenched with excess catalase to a concentration of $62.5 \mathrm{U} / \mathrm{ml}$ to quickly consume any residual hydrogen peroxide, microfiltered and then tested for the residual concentration by using a HPLC-UV (Mazloum, 2014). All reactions were carried out in triplicate. The study was designed to achieve at least $95 \%$ conversion of aromatic substrate by optimising the following parameters: $\mathrm{pH}$, SBP concentration and hydrogen peroxide-to-substrate molar concentration ratio.

Experiments were also conducted to monitor the substrate and hydrogen peroxide consumption over time. The experiments were conducted under the optimum enzymatic conditions to achieve at least 95\% conversion of aromatic substrates (Feng et al., 2013; Steevensz et al., 2009).

\section{Results and discussion}

The following sections present the optimisation of the enzymatic conversion of the BZ, DCB, DMB and DMXB monomers into polymeric products.

\section{Optimum pH}

The optimum $\mathrm{pH}$ for the enzymatic conversion of $\mathrm{BZ}$ was investigated in defined buffers over the $\mathrm{pH}$ range $3 \cdot 8-10 \cdot 6$. SBP is active over a wide range of $\mathrm{pH}(2 \cdot 0-10 \cdot 0)$ (Mazloum, 2014). Batch reactors were run for $3 \mathrm{~h}$ with initial substrate concentrations of $0 \cdot 1$ and $0 \cdot 1 \mathrm{mM}$ hydrogen peroxide with an enzyme activity of

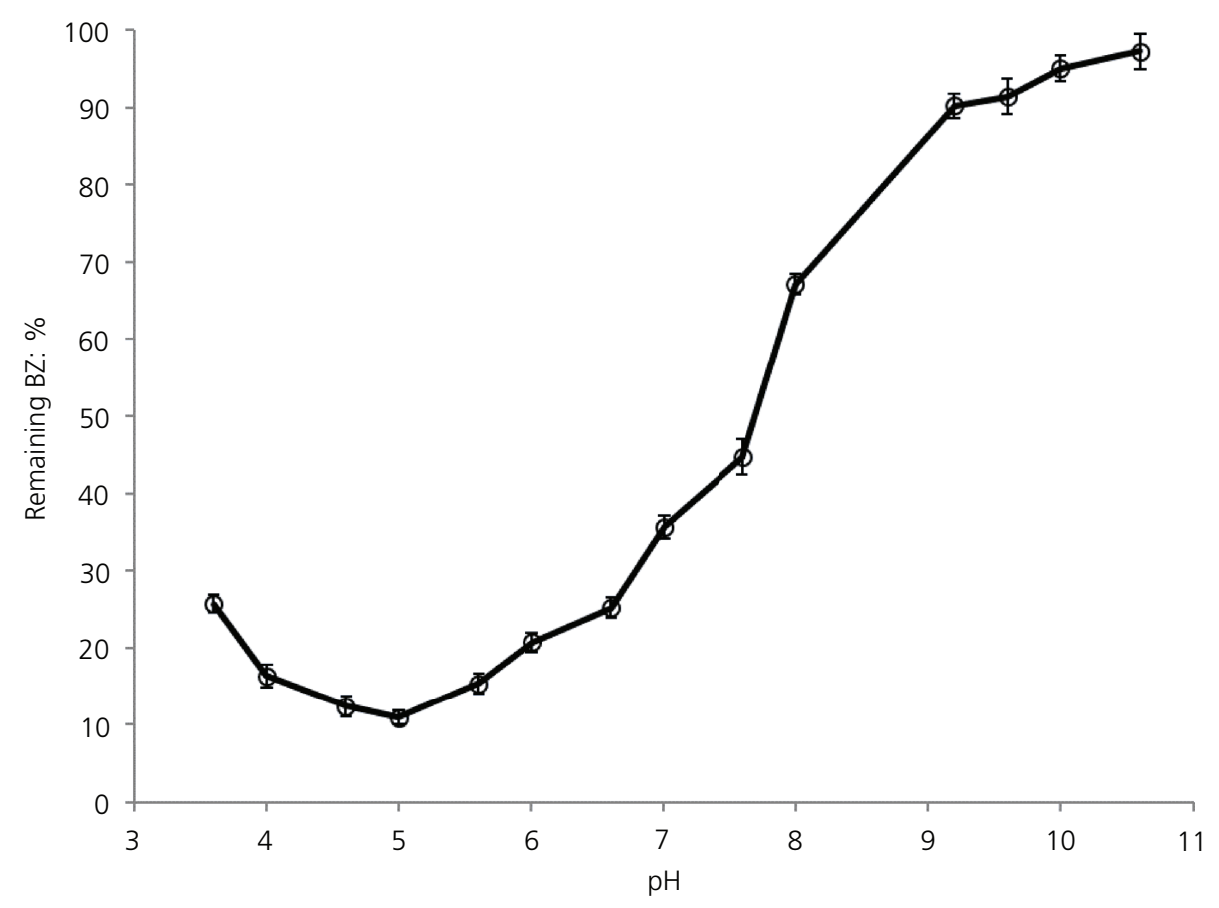

Figure 1. Effect of $\mathrm{pH}$ on removal of $0.1 \mathrm{mM}$ BZ by $1 \mathrm{mU} / \mathrm{ml}$ SBP with $0.1 \mathrm{mM}$ hydrogen peroxide, $3 \mathrm{~h}$ reaction time 


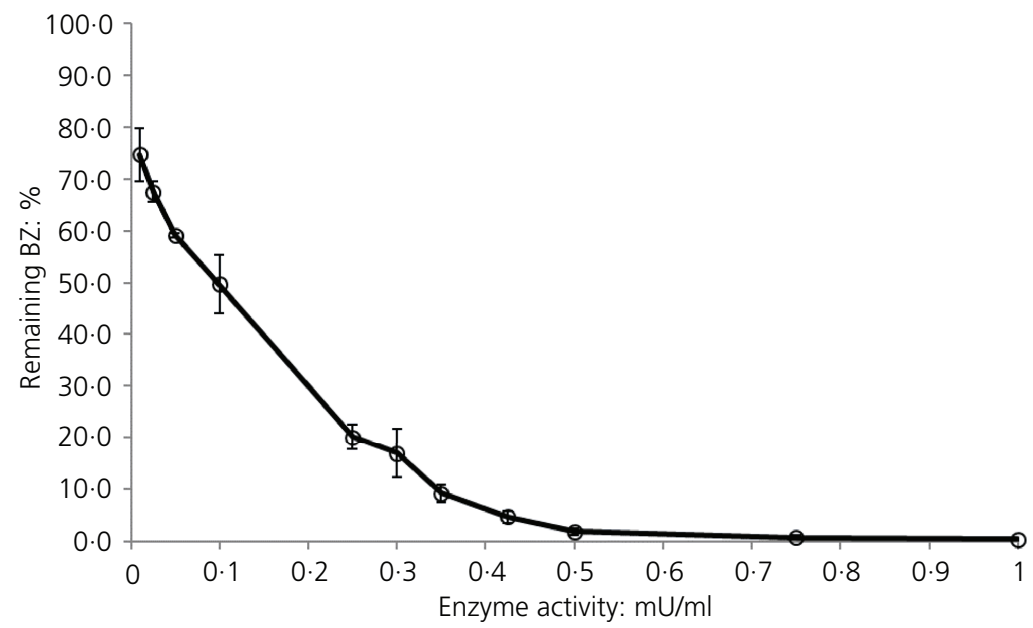

Figure 2. SBP optimisation for the removal of $0.1 \mathrm{mM} \mathrm{BZ}$ in the presence of $0.15 \mathrm{mM}$ hydrogen peroxide at $\mathrm{pH} 5.0,3 \mathrm{~h}$ reaction time

$1 \mathrm{mU} / \mathrm{ml}$. The experiments were designed to test the effect of $\mathrm{pH}$ in the presence of limited SBP concentration. Thus, stringent conditions existed (insufficient SBP for complete conversion of the BZ) in order to clearly determine $\mathrm{pH}$ effect (Figure 1). The optimum $\mathrm{pH}$ for the enzymatic conversion of $\mathrm{BZ}$ was in the slightly acidic region, $4 \cdot 5-5 \cdot 6$. The optimum $\mathrm{pH}$ was $5 \cdot 0$, which is close to the $\mathrm{p} K_{\mathrm{a}}$ of the monoprotonated substrate $(4 \cdot 3$, monoprotonated; 3·3, deprotonated; Zierath et al., 1980). A sharp reduction in the percentage conversion of $\mathrm{BZ}$ was observed in the basic region when compared to the acidic region, which is possibly due to a change in the ionisation of catalytic residues of the enzyme at high pH (Al-Ansari et al., 2009). These results are consistent with those found by others (Karim et al., 2012; Sentchouk and Grintsevich, 2004) by using BGP and TP respectively. It was concluded that the optimum $\mathrm{pH}$ depends not only on the proper ionisation of the catalytic residues of SBP during the enzymatic reaction but also on the type of the aromatic substrate (Al-Ansari et al., 2009).

\section{Minimum SBP concentrations}

Experiments were conducted for $3 \mathrm{~h}$ at the previously established optimal $\mathrm{pH}$ of $5 \cdot 0$ by varying SBP concentrations to determine the minimum SBP required for $\geq 95 \%$ conversion of BZ. All other variables were held constant, hydrogen peroxide at $0.15 \mathrm{mM}$ and $\mathrm{BZ}$ at $0.1 \mathrm{mM}$. The results in Figure 2 show that $\mathrm{BZ}$ required $0.43 \mathrm{mU} / \mathrm{ml}$ of SBP for $95 \%$ removal. A significant change was observed in the range $0 \cdot 1-0.43 \mathrm{mU} / \mathrm{ml}$ of enzyme, and no significant change occurred from 0.43 to $1 \mathrm{mU} / \mathrm{ml}$. This value of $0.43 \mathrm{mU} / \mathrm{ml}$ of SBP for $0.1 \mathrm{mM} \mathrm{BZ}$ may be qualitatively compared to $0.6 \mathrm{U} / \mathrm{ml}$ for $0.5 \mathrm{mM} \mathrm{BZ}$ with BGP (but note the different unit definitions (Karim and Husain, 2011)) and quantitatively compared to $0.6 \mathrm{U} / \mathrm{ml}$ for $1 \mathrm{mM}$ aniline with SBP (same unit definition (Mazloum, 2014)). Relative reactivities are inferred from the inverse radical stabilities, which are estimated from the corresponding homolytic bond dissociation energies, $\mathrm{N}-\mathrm{H}$ for anilines (Jonsson et al., 1994). However, the higher the bond dissociation energy, the more reactive is the radical and the more damaging it is expected to be to the enzyme (Al-Ansari et al., 2009). Free radicals are stabilised by resonance with the aryl ring, and the elongation of conjugation increases the free radical stability (Al-Ansari et al., 2009). The authors speculate that this may be the reason that the enzyme requirement is so low with BZ, relative to aniline for example. Radical stability will be further discussed in 'Time course with a mixture of BZ, DCB, DMB and DMXB'.

\section{Optimum hydrogen peroxide-to-substrate concentration} ratio

The molar concentrations of hydrogen peroxide studied were between $0 \cdot 1$ and $0.2 \mathrm{mM}$ for chemical (the control) and enzymatic reactions. In the chemical reaction the results shows that the $\mathrm{BZ}$ is

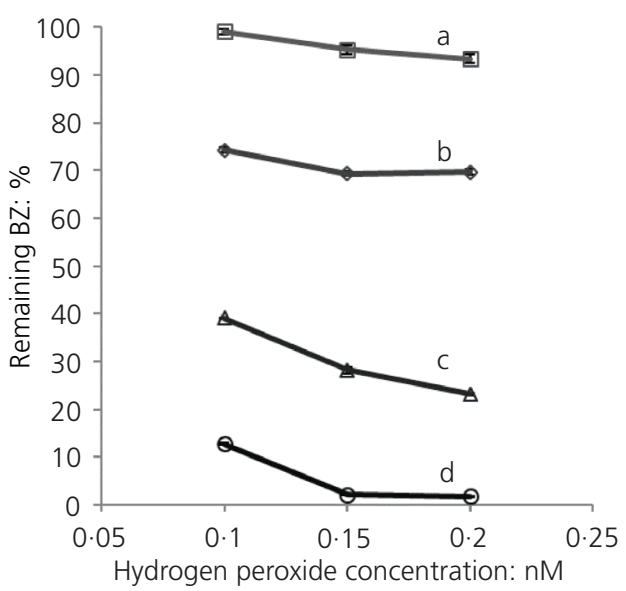

Figure 3. Effect of hydrogen peroxide concentration on the removal of $0.1 \mathrm{mM} \mathrm{BZ}$ by chemical oxidation (a) and enzymatic oxidation with 0.050 (b), 0.25 (c) and $0.75 \mathrm{mU} / \mathrm{ml} \mathrm{SBP}$ (d) at $\mathrm{pH} 5.0,3 \mathrm{~h}$ reaction time 


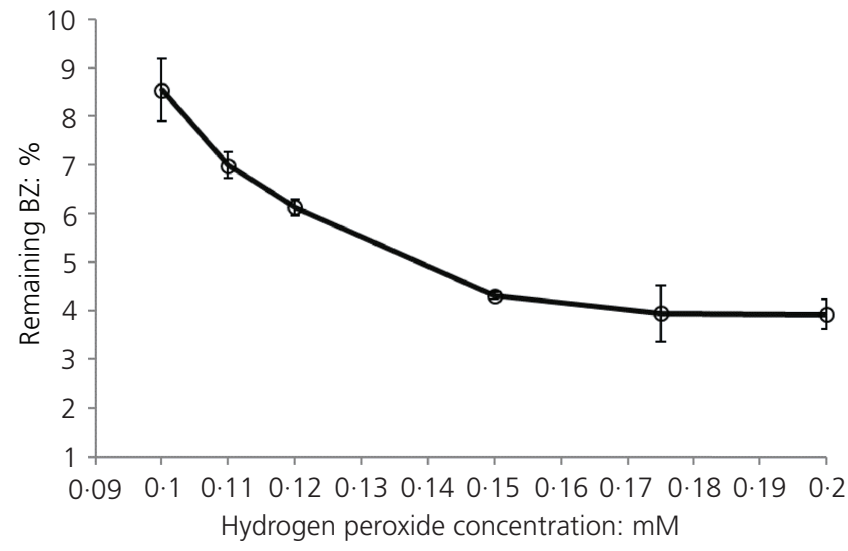

Figure 4. The hydrogen peroxide-to-substrate concentration ratio for $0.1 \mathrm{mM} \mathrm{BZ}$ with SBP at optimum enzyme activity, $0.43 \mathrm{mU} / \mathrm{ml}$, and $\mathrm{pH} 5,3 \mathrm{~h}$ reaction time

slightly sensitive to oxidation by hydrogen peroxide (Figure 3, curve a). In enzymatic oxidation of BZ with enzyme activities of $0.05,0.25$ and $0.75 \mathrm{mU} / \mathrm{ml}$, the results revealed little change in percentage remaining for peroxide concentration beyond $0 \cdot 15 \mathrm{mM}$ (Figure 3, curves b-d).

At optimum conditions, the previously established optimal enzyme activity of $0.43 \mathrm{mU} / \mathrm{ml}$ and $\mathrm{pH} 5$, the requirement of hydrogen peroxide was also studied in detail for enzymatic reaction with $0.1 \mathrm{mM} \mathrm{BZ}$ for $95 \%$ conversion in $3 \mathrm{~h}$ (Figure 4).
The hydrogen peroxide demand was comparable with what is expected theoretically, $0.15 \mathrm{mM}$ of hydrogen peroxide for $0.2 \mathrm{mM}$ of the aromatic functional group, consistent with further polymerisation (Al-Ansari et al., 2010; Yu et al., 1994). Since the soluble dimers produced become substrates of the enzyme (Dunford, 1999), further cycles of polymerisation require additional peroxide. This is consistent with observations for other anilino compounds (Al-Ansari et al., 2009).

\section{Effect of reaction time \\ Benzidine}

The time course for reaction to achieve $95 \%$ removal of $\mathrm{BZ}$ was studied over $3 \mathrm{~h}$. In $250 \mathrm{ml}$ batch reactors under optimal conditions, $0 \cdot 1 \mathrm{mM}$ substrate was treated at $\mathrm{pH} 5$, enzymatic activity of $0.43 \mathrm{mU} / \mathrm{ml}$, and $0.15 \mathrm{mM}$ hydrogen peroxide concentration, and aliquots were withdrawn at various time intervals, quenched with catalase then microfiltered and analysed by HPLC (Figure 5). SBP's catalytic reaction with substrate proceeded rapidly at the start and then slowed down after $30 \mathrm{~min}$. It is evident that a $3 \mathrm{~h}$ reaction time is sufficient to determine the influence of different parameters on achieving at least $95 \%$ removal. Conversion of the substrate continued at a slower rate after the first $30 \mathrm{~min}$, possibly due to competitive conversion of dimers and higher oligomers and/or due to enzyme inactivation caused by the reactive radicals or end-product oligomers (Mazloum, 2014). The rate of reaction should be directly proportional to the enzyme concentration (Dunford, 1999); thus, the reaction would progressively slow down with loss of enzyme activity over the time course. For quantitative analysis, the data were fitted to a pseudo-first-order model, resulting

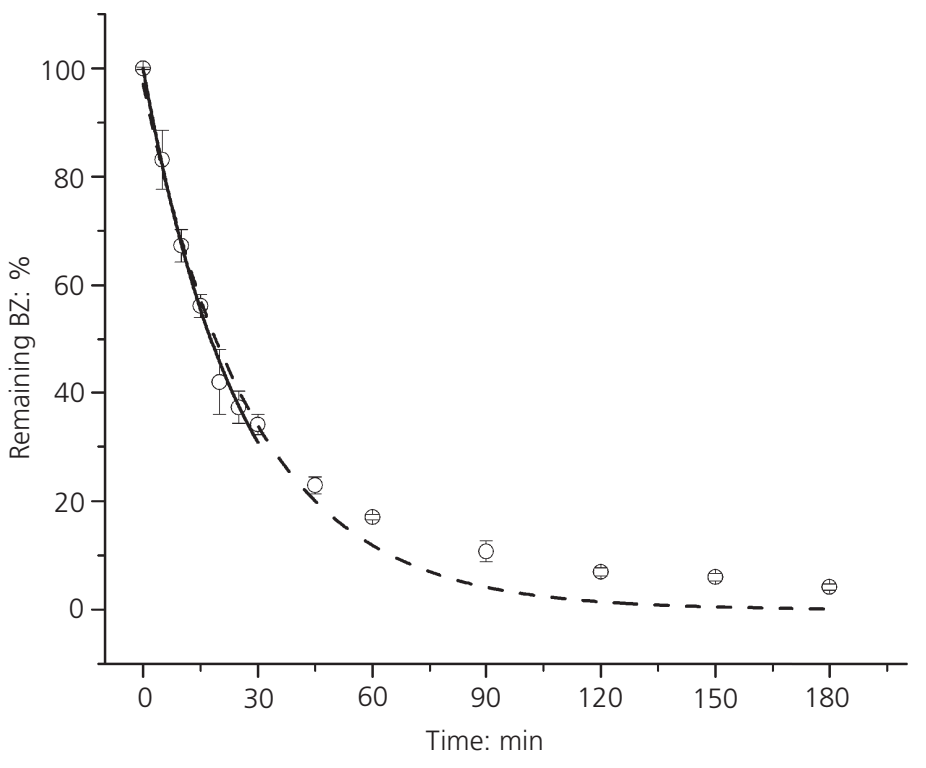

Figure 5. BZ removal with respect to time under optimal conditions: $0.1 \mathrm{mM} \mathrm{BZ}, \mathrm{pH}$ 5, $0.15 \mathrm{mM}$ hydrogen peroxide, $0.43 \mathrm{mU} / \mathrm{ml} \mathrm{SBP}$ and $3 \mathrm{~h}$ reaction time. Lines drawn are from direct fitting by non-linear regression to the first-order decay model, percentage remaining = (initial percentage) $\mathrm{e}^{-k t}$, where the fitted value of the initial percentage should closely approximate $100 \%$ and $k$ is the apparent first-order rate constant. Solid line parameters: $k,(3.92 \pm 0.16) \times$ $10^{-2} \mathrm{~min}^{-1}$; initial percentage, $100.0 \pm 1.6 \% ; R^{2}, 0.9916$. Dashed line parameters: $k,(3.51 \pm 0.25) \times 10^{-2} \mathrm{~min}^{-1}$; initial percentage, $97 \cdot 1 \pm 2 \cdot 6 \% ; R^{2}, 0.9759$ 
Soybean peroxidase-catalysed removal of

benzidines from water

Altahir, Feng, Jasim et al. in the lines drawn in Figure 5. As seen from the fitting statistics in the caption, SBP-catalysed removal of BZ can be well represented as a first-order process over nearly two half-lives of conversion (to $30 \mathrm{~min}$; apparent rate constant $k, 0.039 \mathrm{~min}^{-1}$; half-life: $18 \mathrm{~min}$ ). Even fitting over the whole time course was only slightly less precise, giving a rate constant about $9 \%$ lower with a greater standard deviation. Thus, for comparison purposes in the following section, kinetic analysis was limited to the first $30 \mathrm{~min}$ of the progress curves.

Time course with a mixture of $B Z, D C B, D M B$ and $D M X B$ Under the optimum conditions for $\mathrm{BZ}$ removal, the time course for reaction of a mixture of $\mathrm{BZ}, \mathrm{DCB}, \mathrm{DMB}$ and $\mathrm{DMXB}$ was determined by HPLC to show the relative removal of the four compounds. The combined mixture at $0.16 \mathrm{mM} \quad(0.04 \mathrm{mM}$ of each), $0.24 \mathrm{mM}$ hydrogen peroxide and $0.68 \mathrm{mU} / \mathrm{ml}$ SBP (peroxide and enzyme concentrations were prorated from the optimal values for $0.10 \mathrm{mM} \mathrm{BZ}$ ) and reacted for $3 \mathrm{~h}$ (Figure 6). It is seen that $65-85 \%$ of the BZs were converted during the initial $20 \mathrm{~min}$ of the reaction, with $\mathrm{DCB}$ and $\mathrm{DMB}$ showing slightly higher rates. Kinetic analysis carried out as detailed in the preceding section yielded apparent first-order rate constants given in the caption and ranked as follows: $\mathrm{DCB}>\mathrm{DMB} \geq \mathrm{BZ}>\mathrm{DMXB}$, where the ratio of the fastest to the slowest is only around 2. While this range of relative rate constants is not large, it does parallel what would be expected of the corresponding phenoxy radical reactivities, dichloro being the fastest, dimethoxy being the slowest (i.e. the most stabilised, due to the electron-donating methoxyl substituents), because the removal mechanism consists of enzymecatalysed cycles of radical coupling as outlined in the 'Introduction'.

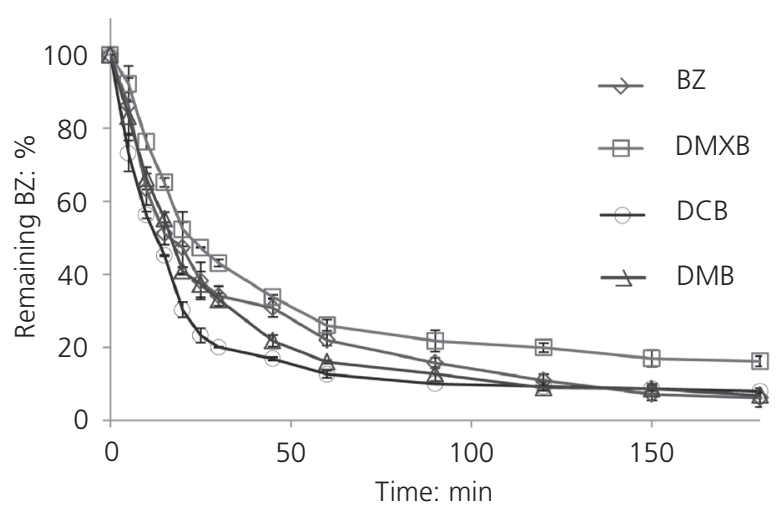

Figure 6. Removal of $B Z$ and its derivatives $D C B, D M B$ and $D M X B$ under prorated optimal conditions for $\mathrm{BZ}$ removal with respect to time. Initial conditions: $0.16 \mathrm{mM}$ of combined substrates $(0.04 \mathrm{mM}$ of each one), $\mathrm{pH} 5,0.24 \mathrm{mM}$ hydrogen peroxide and $0.680 \mathrm{mU} / \mathrm{ml}$ $\mathrm{SBP}, 3 \mathrm{~h}$ reaction time. Kinetic analysis carried out on the $0-30 \mathrm{~min}$ data for each progress curve as described in Figure 5 caption yielded the following apparent first-order rate constants: $B Z_{1}(3 \cdot 90 \pm 0 \cdot 26) \times$ $10^{-2} \mathrm{~min}^{-1} ; \mathrm{DMXB},(2.99 \pm 0.01) \times 10^{-2} \mathrm{~min}^{-1} ; \mathrm{DCB},(5.62 \pm 0.18)$ $\times 10^{-2} \mathrm{~min}^{-1} ; \mathrm{DMB},(4.01 \pm 0.17) \times 10^{-2} \mathrm{~min}^{-1}$
From Figure 6, it is also apparent that the optimum conditions for $95 \%$ conversion of $\mathrm{BZ}$ alone can work fairly well with its derivatives, but in the $3 \mathrm{~h}$ reaction time chosen, their conversion is less complete: $92 \cdot 1 \%$ for dichloro-, $93 \%$ for dimethyl- and $83.8 \%$ for dimethoxy-BZs. Even BZ itself suffered a little in the mutual competition, showing $93 \cdot 87 \%$ conversion. To increase their conversion to at least $95 \%$, a longer time and/or a slightly higher concentration of SBP and/or peroxide would be needed.

\section{Conclusions}

Crude SBP has been shown to be a suitable enzyme for the peroxidase-catalysed polymerisation of $\mathrm{BZ}$ and three of its substituted derivatives; the maximum conversion of these substrates was dependent on the optimal conditions, which were substrate specific. Most notably, the SBP activity required for the complete removal of the compounds was two to three orders of magnitude lower than reported with SBP and simple anilines or another peroxidase and BZ. Thus, SBP-catalysed conversion could, in future work, form the basis of a cost-effective alternative to conventional processes for removal of these four compounds tested from industrial waste and process water.

\section{Acknowledgements}

The authors are grateful to the Ministry of Higher Education in Iraq for providing financial support for this work.

\section{REFERENCES}

Al-Ansari MM, Modaressi K, Taylor KE, Bewtra JK and Biswas N (2010) Soybean peroxidase-catalyzed oxidative polymerization of phenols in coal-tar wastewater: comparison of additives. Environmental Engineering Science 27(11): 967-975, http://dx.doi.org/10.1089/ees.2010.0143.

Al-Ansari MM, Steevensz A, Al-Aasm N et al. (2009) Soybean peroxidase-catalyzed removal of phenylenediamines and benzenediols from water. Enzyme and Microbial Technology 45(4): 253-260, http://dx.doi.org/10.1016/j. enzmictec.2009.07.004.

Al-Kassim L, Taylor KE, Nicell JA, Bewtra JK and Biswas N (1994) Enzymatic removal of selected aromatic contaminants from wastewater by a fungal peroxidase from Coprinus macrorhizus in batch reactors. Journal of Chemical Technology and Biotechnology 61(2): 179-182, http://dx.doi. org/10.1002/jctb.280610214.

Azim SA (2000) Photo-degradation and emission characteristics of benzidine in halomethane solvents. Spectrochimica Acta 56(1): 127-132, http://dx.doi.org/10.1016/S1386-1425(99) 00124-9.

Bayramoglu G and Yakup AM (2007) Biosorption of benzidine based textile dyes Direct Blue 1 and Direct Red 128 using native and heat-treated biomass of Trametes versicolor. Journal of Hazardous Materials 143(1-2): 135-143, http://dx.doi.org/10.1016/j.jhazmat.2006.09.002.

Beland FA and Kadlubar FF (1985) Formation and persistence of arylamine DNA adducts in vivo. Environmental Health Perspectives 62(10): 19-30, http://dx.doi.org/10.2307/3430089. 
Journal of Environmental Engineering and

Science

Volume 10 Issue JS4
Soybean peroxidase-catalysed removal of

benzidines from water

Altahir, Feng, Jasim et al.
Cao XY, Huang G and Cui CW (2007) Benzidines in tannery dye waste water oxidation degradation chloride dioxide. Journal of the Society of Leather Technologists and Chemists 91(4): 145-148.

Caza N, Bewtra JK, Biswas N and Taylor KE (1999) Removal of phenolic compounds from synthetic wastewater using soybean peroxidase. Water Research 33(13): 3012-3018, http://dx.doi.org/10.1016/S0043-1354(98)00525-9.

Cerniglia CE, Freeman JP, Franklin W and Pack LD (1982) Metabolism of azo dyes derived from benzidine, 3,3'dimethylbenzidine and 3,3'-dimethoxybenzidine to potentially carcinogenic aromatic amines by intestinal bacteria. Carcinogenesis 3(11): 1255-1260, http://dx.doi.org/10.1093/ carcin/3.11.1255.

Chung KT and Stevens SE (1993) Degradation of azo dyes by environmental microorganisms and helminths. Environmental Toxicology and Chemistry 12(11): 2121-2132, http://dx.doi. org/10.1002/etc.5620121120.

Do Nascimento GM, Barbosaícia SM, Constantino VRL and Temperini MLA (2006) Benzidine oxidation on cationic clay surfaces in aqueous suspension monitored by in situ resonance Raman spectroscopy. Colloids and Surfaces A: Physicochemical and Engineering Aspects 289(1-3): 39-46, http://dx.doi.org/10.1016/j.colsurfa.2006.04.005.

Dunford HB (1999) Heme Peroxidases. Wiley, New York, NY, USA, pp. 1-36, pp. 270-319, pp. 414-454.

Feng W, Taylor KE, Biswas N and Bewtra JK (2013) Soybean peroxidase trapped in product precipitate during phenol polymerization retains activity and may be recycled. Journal of Chemical Technology and Biotechnology 88(8): 1429-1435, http://dx.doi.org/10.1002/jctb.4075.

Flock C, Bassi A and Gijzen M (1999) Removal of aqueous phenol and 2-chlorophenol with purified soybean peroxidase and raw soybean hulls. Journal of Chemical Technology and Biotechnology 74(4): 303-309, http://dx.doi.org/10.1002/(SICI) 1097-4660(199904)74:4<303::AID-JCTB38>3.0.CO;2-B.

Gomori G (1955) Preparation of buffers for use in enzyme studies. In Methods in Enzymology (Colowick SP and Kaplan NO (eds)). Academic Press, New York, NY, USA, pp. 138-146.

Hao OJ, Kim H and Chiang PC (2000) Decolorization of wastewater. Critical Reviews in Environmental Science and Technology 30(4): 449-505, http://dx.doi.org/10.1080/ 10643380091184237.

Jonsson M, Lind J, Eriksen TE and Merényi G (1994) Redox and acidity properties of 4-substituted aniline radical cations in water. Journal of the American Chemical Society 116(4): 1423-1427, http://dx.doi.org/10.1021/ja00083a030.

Kamal JKA and Behere DV (2003) Activity, stability and conformational flexibility of seed coat soybean peroxidase. Journal of Inorganic Biochemistry 94(3): 236-242, http://dx.doi.org/10.1016/S0162-0134(03)00004-7.

Karagoz B, Bayramoglu G, Altintas B, Bicak N and Arica MY (2011) Amine functional monodisperse micro beads via precipitation polymerization of $N$-vinyl formamide: immobilized laccase for benzidine based dyes degradation.
Bioresource Technology 102(13): 6783-6790, http://dx.doi. org/10.1016/j.biortech.2011.03.050.

Karim Z and Husain Q (2011) Removal of benzidine from polluted water by soluble and immobilized peroxidase in batch processes and continuous horizontal bed reactor. Environmental Technology 32(1): 83-91, http://dx.doi.org/ 10.1080/09593330.2010.487547.

Karim Z, Husain Q and Adnan R (2012) Redox-mediated polymerization and removal of benzidine from model wastewater catalyzed by immobilized peroxidase. African Journal of Biotechnology 11(57): 12053-12062, http://dx.doi. org/10.5897/AJB11.4228.

Lakshmi VM, Hsu FF and Zenser TV (2003) Transformation and activation of benzidine by oxidants of the inflammatory response. Chemical Research in Toxicology 16(3): 367-374, http://dx.doi.org/10.1021/tx0200966.

Mazloum S (2014) Soybean Peroxidase Catalysis in Removal of Anilines and Azo-Dyes from Water. PhD thesis, University of Windsor, Windsor, ON, Canada.

McEldoon JP and Dordick JS (1996) Unusual thermal stability of soybean peroxidase. Biotechnology Progress 12(4): 555-558, http://dx.doi.org/10.1021/bp960010x.

Muneer M, Singh HK and Bahnemann D (2002) Semiconductormediated photocatalysed degradation of two selected priority organic pollutants, benzidine and 1,2-diphenylhydrazine, in aqueous suspension. Chemosphere 49(2): 193-203, http://dx.doi.org/10.1016/S0045-6535(02)00190-X.

Nicell JA, Al-Kassim L, Bewtra JK and Taylor KE (1993) Waste water treatment by enzyme catalyzed polymerization and precipitation. Biodeterioration Abstracts 7(1): 1-8.

Powell R, Murray M, Chen C and Lee A (1979) Survey of the Manufacture, Import and Uses for Benzidine, Related Substances and Related Dyes and Pigments. Office of Toxic Substances, Environmental Protection Agency, Washington, DC, USA, EPA Report 2/800/01/366/01.

Saeed WN (2014) Removal of azo benzidine reactive dye from aqueous solution by adsorption onto $\mathrm{ZnO}$ surface. Journal of Kerbala University 1(12): 11-18.

Saha B, Taylor KE, Bewtra JK and Biswas N (2008) Laccasecatalyzed removal of diphenylamine from synthetic wastewater. Water Environment Research 80(11): 2118-2124, http://dx.doi.org/10.2175/106143008X304712.

Sentchouk VV and Grintsevich EE (2004) Oxidation of benzidine and its derivatives by thyroid peroxidase. Biochemistry (Moscow) 69(2): 201-207, http://dx.doi.org/10.1023/ B:BIRY.0000018952.27498.58.

Sessa DJ and Anderson RL (1981) Soybean peroxidases: purification and some properties. Journal of Chemical Technology and Biotechnology 29(5): 960-965, http://dx.doi. org/10.1021/jf00107a019.

Steevensz A, Al-Ansari MM, Taylor KE, Bewtra JK and Biswas N (2009) Comparison of soybean peroxidase with laccase in the removal of phenol from synthetic and refinery wastewater samples. Journal of Chemical Technology and Biotechnology 84(5): 761-769, http://dx.doi.org/10.1002/jctb.2109. 
Journal of Environmental Engineering and Science

Volume 10 Issue JS4
Soybean peroxidase-catalysed removal of

benzidines from water

Altahir, Feng, Jasim et al.
Wilberg K, Assenhaimer C and Rubio J (2002) Removal of aqueous phenol catalyzed by a low purity soybean peroxidase. Journal of Chemical Technology and Biotechnology 77(7): 851-857, http://dx.doi.org/10.1002/jctb.646.

Wright $\mathrm{H}$ and Nicell JA (1999) Characterization of soybean peroxidase for the treatment of aqueous phenols. Bioresource Technology 70(1): 69-79, http://dx.doi.org/10.1016/S09608524(99)00007-3.

Wu Y, Taylor KE, Bewtra JK and Biswas N (1997) Comparison of additives in the removal of phenolic compounds by peroxidase-catalyzed polymerization. Water Research 31(11): 2699-2704, http://dx.doi.org/10.1016/S0043-1354(97) 00119-X.
Yu J, Taylor KE, Zou H, Biswas N and Bewtra JK (1994) Phenol conversion and dimeric intermediates in horseradish peroxidase-catalyzed phenol removal from water. Environmental Science and Technology 28(12): 2154-2160, http://dx.doi.org/10.1021/es00061a025.

Zierath DL, Hassett JJ, Banwart WL, Wood SG and Means JC (1980) Sorption of benzidine by sediments and soils. Soil Science 129(5): 277-281, http://dx.doi.org/10.1097/ 00010964-198005000-00003.

Zougar S, Baali S, Jaffrezic RN and Kherrat R (2014) Gold electrode functionalized with tridodecylamine for impedimetric detection of Acid Orange 10. Sensors \& Transducers 27(Special Issue): 385-390.

\section{WHAT DO YOU THINK?}

To discuss this paper, please submit up to 500 words to the editor at journals@ice.org.uk. Your contribution will be forwarded to the author(s) for a reply and, if considered appropriate by the editorial panel, will be published as a discussion in a future issue of the journal. 